\title{
Effect of Role School Committee and School Operational Fund on Quality of Education
}

\author{
Rusdi Efendi \\ SMP Negeri 5 Sungai Rotan \\ e-mail: rusdiefendi1974@gmail.com \\ Happy Fitria \\ Universitas PGRI Palembang \\ e-mail: happyfitriamufly@univpgri-palembang.ac.id \\ Nurkhalis \\ Universitas PGRI Palembang \\ e-mail: nurkhalis@univpgri-palembang.ac.id \\ Article History: Received on 1 October 2020, Revised on 11 October 2020, \\ Published on 14 October 2020
}

\begin{abstract}
This study determined whether there is any influence and how much influence the role of the school committee and school operational assistance programs on the quality of education. This research was conducted in SMP Negeri Rambang, Muara Enim. This type of research is quantitative research. While the method in this research uses the partial correlation method. The sample in this study were 45 educators and teaching staff at the school. The data collection technique in this study used a questionnaire. The results of this study showed that 1) there is a relationship between the role of the school committee and the school operational assistance program; 2) there is an influence between the role of the school committee on the quality of education; 3) there is an influence between the school operational assistance program on the implementation of education quality; and 4) there is a significant joint effect between the role of the school committee and the school operational assistance program on the quality of education.
\end{abstract}

Keywords: The Role of the School Committee, School Operational Funds Program, Quality of Education

\section{A. Introduction}

Indonesia is a developing country, education is a benchmark for a government, providing financial assistance through improving the quality of education can improve the quality of a country's human resources. Quality human resources are more important than the wealth of natural resources, because the wealth of natural resources cannot guarantee the welfare and success of a nation (Asvio et al, 2019). Education is a conscious effort to build quality human resources to compete (Tobari et al, 2018).

In this regard, the government continues to make efforts to improve the quality of education delivery, among others by issuing a school operational funds program which is a replacement for a reduction in fuel oil subsidies and in connection with the completion of compulsory 9 year basic education which is intended for students to obtain basic education services more 
quality. The government has programmed the provision of school operational funds for Public or Private SD/MI/SDLB/SMP/MTs/SMPLB and Salafiyah Islamic boarding schools as well as non-Islamic religious schools equivalent to SD and SMP which hold compulsory 9 year basic education. Schools play a role in supporting the program by using these funds as effectively as possible to improve the quality of learning.

One of the government programs in the education sector that has received a fairly large budget allocation is the school operational funds program. School operational funds are funds from the central government to all schools and independent learning activities, both public and private in all provinces in Indonesia. School operational assistance aims to provide assistance to schools in order to free education costs for poor students and make it easier for other students, so that they get quality education services (Kemendikbud, 2013).

In order to achieve the goals of national education, it is necessary to have community participation and financial support in encouraging citizens to participate in adjusting the social and cultural conditions in which the education is carried out. One of the financial inputs received by schools in realizing national education goals is the school operational fund program. In general, the school operational fund program aims to ease the burden on the community on education funding in the context of quality 9 year compulsory education. Meanwhile, the school operational fund program specifically aims to: 1) Free up fees for all students of Negeri SD/SDLB and SMP/SMPLB/SMPT Negeri on school operating costs; 2) exempt all fees for poor students from all levies in any form, both in public and private schools; 3 ) ease the burden of school operational costs for students in private schools.

Meanwhile, the amount of unit cost for school operational assistance received by the school is calculated based on the number of students with the following provisions: a) SD: Rp. 800,000, - / student / year; b) Junior high school: Rp. 1,000,000, - / student / year; c) SMA: Rp. 1.4000.000, - / student / year; d) SMK: Rp. 1,600,000, - / student / year; e) SDLB, SMPLB and SLB: Rp. 2,000,000, - / student / year. School operational funds that are received by the school, are then managed by an implementing organization called the School Operational Funds Management Team which consists of the person in charge (the school principal), the school operational fund treasurer and one member of the community outside the school committee, elected by the school principal and school committee (Permendikbud No. 101 of 2014 concerning Technical Guidelines for the Use of School Operational Funds in 2014).

Based on National Minister of Education Number 044/U/2002 concerning the Establishment of School Committees, where the school committee is an independent body / institution domiciled in each educational unit. The establishment of school committees is aimed at: 1) accommodating and channeling community aspirations and initiatives in creating operational policies and educational programs in educational units; 2) increasing responsibility and community participation in the delivery of education in educational units; 3) create a transparent, accountable and democratic atmosphere and conditions in the implementation and quality of education services in educational units.

Meanwhile, the relationship between the school committee and the education unit and other institutions that are responsible for education management is coordinative. In the education system the roles and functions of the school committee based on the Kepmendiknas Number 044 / U / 2002, the school committee has four main roles in carrying out its duties, namely: 1) 
advisory agency in determining and implementing education policies in educational units; 2 ) supporting agencies, either in the form of finance, thoughts or personnel in the provision of education in educational units; 3) controlling agency in the framework of transparency and accountability of education delivery and output in educational units; and 4) mediator between the government (executive) and the community in the education unit.

The functions of the school committee (Kepmendiknas Number 044 / U / 2002) are: a) to encourage the growth of public attention and commitment to quality education; b) collaborating with the community (individuals / organizations / business world / industrial world) and the government with regard to the provision of quality education; c) accommodate and analyze the aspirations, ideas, demands, and various educational needs put forward by the community; d) provide input, considerations, and recommendations to education units regarding education policies and programs and the School Education and Expenditure Budget Plan; e) encourage parents and the community to participate in education to support the improvement of the quality and equity of education; f) raising public funds in the framework of financing the implementation of education in education units; and g) evaluating and supervising educational policies, programs, implementation and outputs in educational units.

Based on the results of the discussion above, it can be argued that the school committee has a very big role in improving the quality of education if it is properly functioned and empowered by educational institutions. Then the school operational assistance program also makes a major contribution to improving the quality of education if it is properly managed and allocated according to the target and utilization of school operational funds.

This research was conducted at SMP Negeri Rambang Subdistrict, Muara Enim Regency. The researcher chose this school as the research location because SMP Negeri Rambang Subdistrict, Muara Enim Regency is one of the schools that stands in the adjacent Muara Enim Regency in Prabumulih Municipality. In general, SMP Negeri Rambang Subdistrict, Muara Enim Regency. Researchers are junior high schools that have sufficiently good teaching staff and facilities. However, SMP Negeri Rambang Subdistrict has yet to achieve the achievements of the school and the achievements of students, both at the local and national levels. Then, most of the graduates at SMP Negeri Rambang Subdistrict have not yet continued to general or vocational high schools. Seeing this condition, the researchers decided to carry out research at the State Junior High School of Rambang Subdistrict, Muara Enim Regency, totaling 4 schools, namely SMP Negeri 1 Rambang in Sugih Waras Village, SMP Negeri 2 Rambang in Sugihan Village, SMP Negeri 3 in Talang Pengadang and SMP Negeri 4. Rambang in Marga Mulya village.

Based on the results of preliminary observations made by researchers on Tuesday, September 3, 2019 at the Rambang Subdistrict Negeri Junior High School, the researcher put forward several indicators that state the direct involvement of the school committee in the implementation of education at SMP Negeri Rambang Subdistrict. This can be seen where the school committee pays attention and builds commitment with the community to support school programs aimed at improving the quality of SMP Negeri Rambang Subdistrict. In addition, the school committee also plays a role as a liaison for partnerships between companies and government agencies and SMP Negeri Rambang Subdistrict through practical fieldwork activities and also building facilities and infrastructure to improve the quality of education which is confirmed through a memorandum of understanding. Then the school committee at SMP Negeri Rambang Subdistrict also plays a role in accommodating the ideas 
and aspirations of the community, especially regarding improving the quality of education at SMP Negeri Rambang Subdistrict.

There are several problems encountered by researchers, related to the role of the school committee at SMP Negeri Rambang Subdistrict, such as only some school committee administrators actively participate in monitoring teaching and learning activities in schools, as well as in school committee plenary meetings held at schools, this indicates a support from some school committees for the quality of education. This can be seen from several committee meetings held by the school, participants who attended an average of only $20 \%$ to $30 \%$ of the school committee members of the total school committees in SMP Negeri Rambang Subdistrict. Then there are some school committee administrators who expect to benefit or be given wages / salaries in carrying out their role as school committee. This indicates that some school committees do not yet understand their role as a school committee.

The next problem is that there is often unequal perception between school principals and some school committees regarding the implementation of school activities. Zulkifli (2015) in his research stated that in carrying out the education process, it would also not run well if there was no collaboration between all parties. In this case, the related parties help each other and have their respective duties and roles, such as the principal, the teacher council, the school committee, and the community. From this opinion, it is clear that in efforts to improve the quality of education, school committees and school principals must establish good relationships.

The problems found by researchers are supported by research conducted by Sholihat (2017) with the results of research suggesting that community participation through madrasah committees at Private Madrasah Ibtidaiyah in Bandung City, if you look at the four dimensions of madrasah committees, the highest dimension is giving consideration to indicators of identifying educational resources in the community, providing input in the preparation of the RKAS, participating in validating the RKAS with the head of madrasah and providing input on the education management process. Meanwhile, the lowest dimension is supporters with indicators of mobilizing volunteer teachers to overcome teacher shortages in madrasah and mobilizing educational personnel (not teachers) to fill gaps in madrasah. In order for this dimension to increase, the school committee must play an active role in supporting any madrasah programs, especially in learning activities.

The school committee can be pursued by optimizing the role of each member of the school committee, the involvement of all elements in the school committee organization and the division of tasks in accordance with the capacity of personnel will be able to improve the performance of the school committee. In addition, the researchers also found indicators for the management of funds for the school operational assistance program at SMP Negeri Rambang Subdistrict, among others, the RKAS planning for SMP Negeri Rambang District was prepared by the school budget team, to plan the school work budget for one year. The budget is prepared based on a collection of activities from teachers and employees of each field. The interim plans that have been drawn up are then communicated to the School Committee to ask for considerations that need to be implemented in that fiscal year.

Then the bookkeeping of school operational funds is made including general cash books, bank auxiliary books, and tax auxiliary books. Tax payments for the management of operational funds for junior high schools include PPN, PPh articles 21 and 22. In addition, 
monitoring and evaluation of the management of operational funds for SMP Negeri Rambang District schools are carried out by internal and external parties. Management of school operational funds is reported to the District, Provincial and Central Education Offices.

As with the role of the school committee, there are several problems encountered by researchers related to the management of school operational funds, including: 1) the management of school operational funds is still not maximal, because school operational funds are still not sufficient to cover all school operational needs; 2) management of school operational funds is still not transparent; 3) still processing / recording financial reports of school operational funds manually. So that the possibility of human error such as errors in data input is very possible; and 4) there are still delays in the disbursement of school operational funds to schools.

From the results of the preliminary observations made by the researchers above, the researcher can argue that the role of the school committee has not been going well and the management of school operational funds program has not been managed properly, when seen from several problems faced regarding the role of the school committee and fund management school operational funds as stated above. Therefore, it is necessary to carry out further research, whether the role of the school committee and the management of school operational funds program in SMP Negeri Rambang Subdistrict, Muara Enim Regency have an influence on improving the quality of education, and how much influence does it have on improving the quality of education in these schools. Therefore, researchers are interested in examining whether the role of the school committee and the management of school operational funds that have been running well in SMP Negeri Rambang Subdistrict have an effect on the quality of education at SMP Negeri Rambang Subdistrict, Muara Enim Regency.

\section{B. Methods}

This type of research is quantitative research. While this research method uses the partial correlation method, partial correlation is used for analysis or hypothesis testing if the researcher intends to determine the effect or relationship of the independent variable with the dependent, where one of the independent variables is controlled (made fixed) (Sugiyono, 2007).

Population is a generational area consisting of objects or subjects that have certain qualities and characteristics that are determined by researchers to study and then draw conclusions (Sugiyono, 2008). Meanwhile, according to Arikunto (2010) the population is the whole of the research subjects. Akbar (2006) states that population is all values both calculated and measured, both quantitative and qualitative, rather than certain characteristics regarding a group of objects that are complete and clear. Then according to Riduwan (2012), the population is an object or subject that is in an area and meets certain conditions related to research problems. The population in this study were educators and education personnel at SMP Negeri Rambang Subdistrict, Muara Enim Regency, which consisted of 45 people.

The number of population is below 100, the researchers took the entire population to be the research sample, namely 45 people. This is in accordance with the opinion of Arikunto (2010) which states that if the subject is less than 100 people, all of them should be taken, if the subject is large or more than 100 people can be taken $10-15 \%$ or $20-25 \%$ or more. The 
Volume 1 (2) 2020

E-ISSN: 2723-6919 P-ISSN:2746-0827

data collection techniques in this study used a questionnaire that had been tested for validity and reliability.

The test requirements for the analysis of research data used the normality, homogeneity and linearity test. For data analysis using multiple linear regression analysis. Riduwan (2012) states that multiple regression is a tool for forecasting the value of the effect of independent variables or more on the dependent variable.

Based on the significance test of the school operational funds program variable on the quality of education in SMP Negeri Rambang, Muara Enim Regency, it was obtained that the $t_{\text {value }}$ was $3.171 \geq$ the $t_{\text {table }}$ price of 0.679 where the $t_{\text {value }}$ was greater than the $t_{\text {table }}$ so $\mathrm{H}_{02}$ was rejected, so there was a significant influence school operational funds program for the implementation of quality education in SMP Negeri Rambang Subdistrict, Muara Enim Regency.

\section{Results and Discussion}

The Joint Effect between the Role of the School Committee and the School Operational Funds Program on the Quality of Education in SMP State Rambang Subdistrict, Muara Enim Regency

Table 1. The Results of the Multiple Regression Analysis $X_{1}$ and $X_{2}$ on $Y$ ANOVAb

\section{Sum of}

\begin{tabular}{|c|c|c|c|c|c|}
\hline Model Squares & Df Mea & Square & $\mathrm{F}$ & Sig. & \\
\hline 1 & Regression & 1863.035 & 2 & 931.518 & $3239.781 .000^{b}$ \\
\hline Residual & $12.076 \quad 42$ & & .288 & & \\
\hline Total & 1875.11144 & & & & \\
\hline
\end{tabular}

a. Predictors: (Constant), $X_{1}, X_{2}$

b. Dependent Variable: $Y$

Source: Data Processing Using SPSS 22.00

Table 2. Coefficient of Determination Model Summary

Adjusted $R \quad$ Std. Error of the

Model R Square Square Estimate

$\begin{array}{lllll}1 & .997 \mathrm{a} & .994 & .993 & .53621\end{array}$

a. Predictors: (Constant), Variabel $X_{2}, X_{1}$

Source: Data Processing Using SPSS 22.00

Based on the results of the analysis above, it can be argued that there is a significant relationship between the variable role of the school committee and the school operational funds program at SMP State Rambang Subdistrict Muara Enim, based on the significant value between the school committee variable and the school operational funds program 
variable of $0.00>0.05$. Then there is a significant influence between the role of the school committee on the quality of education in SMP State Rambang Subdistrict, Muara Enim Regency, Banyuasin Regency. Based on the significance test of the variable role of the school committee on the quality of education in SMP State Rambang Subdistrict, Muara Enim Regency, the $t_{\text {value }}$ is $16,930>$ from the $t_{\text {table }}$ price of 0.679 where the $t_{v a l u e}$ is greater than the $\mathrm{t}_{\text {table }}$, then $\mathrm{H}_{01}$ is accepted.

Then there is a significant influence between the school operational funds program on the implementation of the quality of education in SMP State Rambang Subdistrict, Muara Enim Regency. Based on the significance test of the school operational funds program variable on the quality of education in SMP State Rambang Subdistrict, Muara Enim Regency, the $t_{\text {value }}$ is $3.171 \geq$ the $t_{\text {table }}$ price of 0.679 where the $t_{\text {count }}$ price is greater than the $t_{\text {table }}$ then $H_{02}$ is accepted.

In testing the last hypothesis, it can be concluded that there is a significant influence jointly between the role of the school committee and the school operational assistance program on the quality of education in SMP State Rambang Subdistrict Muara Enim Regency. Based on the Anova test, it is obtained that $\mathrm{F}$ count is 3239.781 with a significance level of 0.000 <probability value $\alpha 0.05$ while $\mathrm{F}$ table corresponds to the significance level of 0.05 (1.42) of 4.08 so that $\mathrm{F}_{\text {count }}>\mathrm{F}_{\text {table }}(3239.781>3.22)$ so that $\mathrm{H}_{04}$ is rejected.

The big influence of the role of the school committee and the school operational funds program on the quality of education in SMP State Rambang Subdistrict Muara Enim Regency together is $99.4 \%$ and the remaining $0.6 \%$ is influenced by other factors not examined in this study. This is based on the $\mathrm{R}$ square value of 0.994 , thus the coefficient of termination is $99.4 \%$.

The results of this study are supported by the results of previous research, including research conducted by Hadiyanto (2017) with the results of testing the main hypothesis showing that the implementation of the policy of providing school operational funds has a positive and significant effect on improving teacher performance and the participation of parents in students. The increase in student achievement was $27.81 \%$, while the influence outside the implementation of school operational funds policies was $72.19 \%$. The results of the subhypothesis testing show that each variable has a positive and significant effect.

Makmun et al, (2014) with the results of research showing that the formation of the committee has referred to the provisions of laws and regulations and involves elements of the teacher council, society, government and the business and industrial world. The prominent role of the school committee is related to providing consideration and support, while the role of the committee as a controller is still limited in the use of the school budget and does not touch on academic issues and school performance evaluation. Likewise, the role of mediation is supported by stakeholders, considering that SMP Negeri, Rambang Subdistrict, Muara Enim Regency requires cooperation with many elements. The school committee as an independent organization is very helpful in realizing education at SMP Negeri Rambang Subdistrict, Muara Enim Regency.

Larasati (2009) with the results of the study, it can be seen that not all roles of the school committee have been carried out. In carrying out its duties and roles, there are still deficiencies. The role of the school committee as a provider of consideration is manifested in 
the form of giving consideration to the provision and use of facilities and infrastructure needed by the school. The school committee also gives consideration to the use and utilization of budgets or funds obtained by schools, providing input on the draft school income and expenditure budget. The role of the school committee as support is in the form of material and moral support.

Bhawa, Haris, and Artana (2014) with the results of research showing that 1) the management of school operational funds in all elementary schools is in accordance with Permendiknas No. 76 regarding technical guidelines for the use and financial accountability of school operational funds in $2013 ; 2$ ) the level of effectiveness in the management of school operational funds in all primary schools reached $87 \%$, which is in the very effective criteria; 3) problems faced by all elementary schools, namely school operational funds arriving not on time, and the committee does not understand the management of school operational funds; 4) the efforts made by all elementary schools, namely making loans and shopping on credit, and strengthening the committee related to school operational funds.

\section{Conclusion}

Based on data analysis and hypothesis testing, the following conclusions can be drawn: a) there is a significant relationship between the role variable of the school committee and the school operational assistance program at SMP State Rambang Subdistrict Muara Enim Regency, based on the significant value between the school committee variable and the school operational assistance program variable equal to $0.00<$ of 0.05 ; b) there is a significant influence between the role of the school committee on the quality of education in SMP State Rambang Subdistrict Muara Enim Regency. Based on the significance test of the role of the school committee variable on the quality of education in SMP State Rambang Subdistrict, Muara Enim Regency, the $t_{\text {count }}$ value is $16,930>$ from the $t_{\text {table }}$ price of 0.679 where the $t_{\text {value }}$ is greater than the $t_{\text {table }}$ then $\mathrm{H}_{01}$ is accepted; c) there is a significant influence between the school operational funds program on the implementation of the quality of education at SMP State Rambang Subdistrict, Muara Enim Regency. Based on the significance test of the school operational funds program variable $\left(\mathrm{X}_{2}\right)$ on the quality of education (Y) in SMP State Rambang Subdistrict, Muara Enim Regency, the $t_{v a l u e}$ is $3.171 \geq$ the $t_{\text {table }}$ price of 0.679 where the $t_{\text {count }}$ price is greater than the $t_{\text {table }}$ then $\mathrm{H}_{02}$ is accepted; $d$ ) there is a significant influence jointly between the role of the school committee and the school operational funds program on the quality of education in SMP State Rambang Subdistrict Muara Enim Regency.

Based on the Anova test, it is obtained that $\mathrm{F}_{\text {count }}$ is 3239.781 with a significance level of $0.000<$ probability value $\alpha 0.05$, while $F_{\text {table }}$ corresponds to a significance level of 0.05 (1.42) of 4.08 so $\mathrm{F}_{\text {count }}>\mathrm{F}_{\text {table }}(3239.781>3.22)$ so that $\mathrm{H}_{04}$ is boxed. As for the great influence of the role of the school committee and the school operational funds program on the quality of education in SMP State Rambang Subdistrict, Muara Enim Regency together, 99.4\% and the remaining $0.6 \%$ influenced by other factors not examined in this study. This is based on the $\mathrm{R}$ square value of 0.994 , thus the coefficient of termination is $99.4 \%$.

\section{E. Conclusion}

Based on the results of the study, there are positive implications of the influence of the role of the school committee and the school operational funds program on the quality of education in SMP State Rambang Subdistrict, Muara Enim Regency. The implications that can be drawn from the research results are as follows: 1) the role of the school committee is very important 
Volume 1 (2) 2020

E-ISSN: 2723-6919 P-ISSN:2746-0827

as a supervisor in managing school operational funds. This of course requires a school committee that has a broad commitment and insight to the needs of the school; 2) schools need to have ongoing cooperation with committees in an open and transparent manner so as to improve the quality of education; 3 ) the existence of a school operational fund program is certainly very helpful in meeting the operational needs of the school so that the quality of education can be in accordance with the national curriculum standards; and 4) cooperation between school committees, school principals and all school members in an effort to improve the quality of education.

\section{E. Acknowledgement}

We thank to the principal of SMP Negeri 5 Sungai Rotan, Rector Universitas PGRI Palembang who gave us the support to do this wonderful project. This project was funded independent. We would also like to thank our friends in Educational Management who helped us a lot in finalizing this project within the limited time frame.

\section{References}

Akbar, S. (2006). Metodologi Penelitian Sosial [Social Research Methodology]. Jakarta: Bumi Aksara.

Arikunto, S. (2010). Prosedur Penelitian Suatu Pendekatan Praktek [Research Procedure A Practice Approach]. Jakarta : Rineka Cipta.

Asvio, N., Yamin, M., \& Risnita. (2019). Influence of Leadership Style, Emotional Intelligence and Job Satisfaction toward Organizational Commitment (Survey at SMA Muhammadiyah South Sumatera). International Journal of Scientific \& Technology Research 8 (8).

Bhawa, G., Haris, A., \& Artana, M. (2014). Efektivitas Pengelolaan Dana Bantuan Operasional Sekolah pada Sekolah Dasar di Kecamatan Sukasada [The Effectiveness of Fund Management for School Operational Fund at Elementary Schools in Sukasada District]. Jurnal Pendidikan Ekonomi UNDIKSHA 4(1).

Hadiyanto, N. (2017). Pengaruh Implementasi Kebijakan Pemberian Bantuan Operasional Sekolah terhadap Peningkatan Kinerja Guru dan Partisipasi Orang Tua Siswa dalam Peningkatan Prestasi Belajar Siswa pada Sekolah Menengah Pertama Negeri di Kabupaten Garut [The Effect of the Implementation of School Operational Funds Policy on Improving Teacher Performance and Parent Participation in Improving Student Achievement at Public Junior High Schools in Garut Regencyl. Jurnal Pendidikan UNIGA 9 (1).

Kementerian Pendidikan dan Kebudayaan. (2013). Petunjuk Teknis Penggunaan Dana Bantuan Operasional Sekolah [Technical Guidelines for the Use of School Operational Funds]. Jakarta: Direktorat Jenderal Pendidikan Dasar Kementerian Pendidikan. 
Kementerian Pendidikan Nasional. (2002). Number 044/U/2002. Pedoman Pembentukkan Komite Sekolah [Guidelines for Establishing School Committees]. Jakarta: Dinas Pendidikan.

Larasati. (2009). Peran Komite Sekolah dalam Meningkatkan Mutu Pendidikan di SMA Ronggolawe Kota Semarang [The Role of the School Committee in Improving the Quality of Education at SMA Ronggolawe Semarang City]. Under Graduates Thesis, Universitas Negeri Semarang.

Makmun, S., \& Ambarita, A. (2014). Peran Komite Sekolah dalam Peningkatan Manajemen Mutu Pendidikan [The Role of School Committees in Improving Education Quality Management]. Jurnal Manajemen Mutu Pendidikan FKIP UNILA, Vol. 2, No. 1.

Peraturan Menteri Pendidikan dan Kebudayaan Republik Indonesia Nomor 101 Tahun 2014 tentang Petunjuk Teknis Penggunaan dan Pertanggungjawaban Keuangan Dana Bantuan Operasional Sekolah Tahun Anggaran 2014 [Regulation of the Minister of Education and Culture of the Republic of Indonesia Number 101 of 2014 concerning Technical Guidelines for the Use and Financial Accountability of School Operational Funds for the 2014 Fiscal Year].

Riduwan. (2012). Belajar Mudah Penelitian Untuk Guru, Karyawan, Peneliti, Pemula [Easy Learning Research For Teachers, Employees, Researchers, Beginners]. Bandung: Alfabeta.

Sholihat, S. (2017). Pengelolaan Biaya Pendidikan, Partisipasi Masyarakat, dan Mutu Layanan Pembelajaran Madrasah Ibtidaiyah Swasta [Management of Education Costs, Community Participation, and Quality of Private Madrasah Ibtidaiyah Learning Services]. Jurnal Administrasi Pendidikan, Vol.XXIV No.1.

Sugiyono. (2007). Metode Penelitian Pendidikan, Pendekatan Kuantitatif, Kualitatif, $R \& D$ [Educational Research Methods, Quantitative Approaches, Qualitative $R \& D$ ]. Bandung: Alfabeta.

Sugiyono. (2008). Metode Penelitian Pendidikan, Pendekatan Kuantitatif, Kualitatif, $R \& D$ [Educational Research Methods, Quantitative Approaches, Qualitative $R \& D$ ]. Bandung: Alfabeta.

Tobari., Kristiawan, M. \& Asvio, N. (2018). The strategy of Headmaster on Upgrading Educational Quality in Asean Economic Community (AEC) Era. International Journal of Scientific \& Technology Research 7 (4).

Zulkifli. (2015). Komite Sekolah diantara Cita dan Realita [School Committee Between Mind and Reality]. Jurnal Potensia, 14(1.) 